\author{
B.R. Nussupbekov ${ }^{1}$, G.T. Kartbaeva ${ }^{1}$, M. Stoev ${ }^{2}$, \\ A.K. Khassenov ${ }^{1}$, D.Zh. Karabekova ${ }^{1}$, A.K. Muratova ${ }^{1}$ \\ ${ }^{l}$ Ye.A. Buketov Karaganda State University, Kazakhstan; \\ ${ }^{2}$ Neofit Rilski South-West University, Blagoevgrad, Bulgaria \\ (E-mail: ayanbergen@mail.ru)
}

\title{
Electrohydroimpulse method of extracting bone grease
}

\begin{abstract}
The extraction of fat is the most important stage of the technological process of production of animal fats. The task of the study is to ensure the extraction of fat from fat cells of adipose tissue. Therefore, there are various technological methods that allow to influence the adipose tissue in such a way as to separate the fat contained in them from the fat cells. Electrohydroimpulse method of extracting bone grease for the production of gelatin was developed. Electrohydroimpulse method of extracting greese from bone mass, characterized in that the bone mass is not subjected to mechanical shock. In the mixture, a shock wave is formed, which is created by an electrohydroimpulse installation. Tests of the experimental electrohydroimpulse installation for the extraction of greese from the bone mass of cattle were carried out for various bones of cattle. The article shows a diagram of the crushing host of electrohydroimpulse plants for the extraction of greese from bone mass. In laboratory studies, the work on degreasing the crushed bone has been done at different values of the capacitor bank electrohydroimpulse installation, the discharge voltage, the length of the discharge gap on the switching device, the temperature of the mixture and set effective parameters for optimal degreasing of bone mass.
\end{abstract}

Keywords: bone greese extraction, crushing unit, electrohydraulic method, switching device, length of discharge gap.

\section{Introduction}

Extraction of bone grease is the most important task of the technological process of edible animal grease production affecting both the quantitative and qualitative characteristics of the grease processing method. The grease contained in the bone is a great nutritional value, because of its highly digestibility, and contains many unsaturated and polyunsaturated fatty acids and lecithin, and its latter is several times more than in other animal greases.

Regardless of the using final products the technology of processing food bone material firstly provides bone dehydration. The simplest way to extract grease from bone and bone residue is to heat it at atmospheric pressure in open boilers. The degreasing process takes place at a temperature of $90-100^{\circ} \mathrm{C}$ in an aqueous medium. Contact with water eliminates the possibility of adsorption of grease on the surface of particles and reduces its retention in the capillaries of the bone material $[1,2]$.

The boilers are heated with water or steam through the casing, since direct contact of the hot steam with the bone promotes the formation of emulsion and increase in the loss of protein substances with the broths. Removable baskets are provided for the mechanization of loading and unloading raw materials.

The raw material varies depending on the temperature and duration of heating. First of all this refers to gluten which is formed from collagen, and its hydrolysis, which leads to the depletion of bone collagen.

The soft mode of sweating is caused by the need to preserve the mechanical strength of the tubular bone as an ornamental material. In addition, high temperature and prolonged contact of grease with heated bone lead to a deterioration in the organoleptic characteristics of the final product. This explains the moderate temperature conditions not exceeding $90-100{ }^{\circ} \mathrm{C}$ of the bone heating in the open boilers.

Removing grease from the grease source by heating in the open boilers is not completely reached. The greaves consisting of 30-35\% the mass of raw materials contains up to $20 \%$ grease. Greaves degreased on special equipment which requires certain material costs. Grease grade decreases during secondary degreasing of greaves.

As sweating grease in batch apparatus, two thermal methods of obtaining grease are used: dry and wet. The essence of grease extraction by the dry method lies in the fact that the moisture contained in the grease raw material evaporates into the atmosphere or is removed under vacuum after unwelding and during the dehydration process. In this case, the grease contained in the raw material is partially excreted by forming a two-phase system: dry fatty greaves - grease [3, 4]. 
For the final extraction of grease from the greaves we apply pressing or centrifugation. The dry method is practiced when it is necessary to ensure a high yield of benign grease and greaves, and the taste and smell of grease are secondary importance. The adipose tissue is in direct contact with hot water or live steam used to heat the raw materials during the heat treatment process in the wet method of processing fat raw materials. At the same time, most proteins mainly collagen are welded and hydrolyzed to form gluten (broth). The grease released from the raw materials is also partially emulsified. As a result of heat treatment the threephase system is obtained: grease - greaves - grease.

However this method is quite complex in terms of hardware, and leads to loss of bone collagen during grease extraction which leads to a decrease in yield and deterioration in the quality of glue and gelatin produced from skimmed bone. Owing to the duration of the process of draining, grease may acquire the taste and smell of weakly roasted raw materials. At the dry method of grease draining requires a large consumption of steam, cold water and electricity. Complete and thorough destruction of cells and tissue as a whole is achieved only when the raw material is heated to temperatures above $100{ }^{\circ} \mathrm{C}$ and the quality of fat deteriorates sharply in this method. The main disadvantage of dry and wet methods is using equipment of large dimensions and metal with a small heat transfer surface, low heat transfer coefficient [5].

A particularly high degree of grease extraction from bone mass is necessary in case of its subsequent use for the production of photogelatin: the residual grease content in the bone tissue should not exceed $1 \%$ by weight of the bone, therefore it is necessary to remove at least $95 \%$ of the grease originally contained in it. A given degree of grease extraction can be achieved by repeatedly passing the bone through hydromechanical impulse devices, however as long as decrease of the greaset content in the aquatic environment makes it difficult to allocate. The big disadvantage of the pulse hydromechanical method is the strong grinding of the bone with rotating hammers. With a single pass through the apparatus about $30 \%$ of the bone mass is so crushed that it can no longer be used in gelatin production, and with repeated passing the losses increase to $50 \%[6,7]$.

In this regard, electrohydroimpulse method of extracting greese from bone mass is developed in the laboratory of hydrodynamics and heat exchange of Y.A. Buketov Karaganda State University, differ from the bone mass that is not subjected to mechanical shock. A shock wave is formed in the mixture which is created using an electrohydroimpulse installation $[8,9]$.

\section{Results and discussions}

So far, it is not established which of the possible known methods (hydromechanical pulsed, extraction, etc.) of raw bone degreasing ensures the achievement of the greatest economic effect. An experimental electrohydroimpulse installation and the working part of the crushing unit were designed and assembled to study the effect of the underwater spark discharge on crushing and extracting grease from the bone mass and protein from the bone matrix.

Figure shows the diagram of the crushing unit of an electrohydroimpulse installation for extracting grease from bone mass. Before carrying out laboratory work it is necessary to prepare the bone mass of medium fatness. Preliminary preparation of the electrohydroimpulse installation for the performance of work is carried out when disconnected from the network following the rules of safe operation. A negative grounded electrode is connected to the body of the crushing and grinding unit by means of a tire, the cross section of which (for copper) is at least $30 \mathrm{~mm}^{2}$, and the points of direct connection must have a good contact. After that, the control panel of the electrohydroimpulse installation is grounded. Install protective fences to prevent accidental contact with the voltage of workers in the workshop.

Tests of an experimental electrohydroimpulse unit for extracting grease from the bone mass of cattle were carried out for various bones of cattle taken separately in the sausage shop of «Tulpar» JSC in Karaganda. According to the technological estimates of the laboratory of the «Tulpar» JSC workshops, organic compounds (bones) had a small and medium fatness.

Standard differential thermocouples calibrated by temperature, are mounted in the CGU (crushing and grinding unit) to determine the temperature of the mixture. Before conducting the experiments, $20 \mathrm{~kg}$ of the bone material obtained after pressing was crushed to the size of $5-10 \mathrm{~mm}$, divided into certain fractions and weighed on special electronic scales. Then the bone mass was placed in a special container with technical water and left for 6 hours. After the treatment, the impregnated bones were weighed to determine the mass. The bone mass connected to water and heated to a temperature of $32-50^{\circ} \mathrm{C}$ enters the crushing and grinding unit through a guide cone receiver. The mass is subjected to the impact of a shock wave arising from a spark discharge after tightly closing the flap. The intensity of the degreasing process and the possibility of wide 
regulation directly in the course of the process being carried out is achieved by rotating the CGU case relative to the central electrode. The CGU housing is rotated by a motor with an angular speed of $15 \mathrm{rpm} . . . \mathrm{In}$ this case, the working electrode is supplied with a specific energy equal to $2.0 \times 10^{4} \mathrm{~J} / \mathrm{m}$ with a pulse repetition rate of $5 \ldots 14 \mathrm{~Hz}$. The defatted bone from the spark gap falls on the discharge conveyor, and the grease floats up and is further processed through the drainage along with the water. The residual grease content in the bone is about $1.0-1.4 \%$ in the process of a single treatment in the installation.

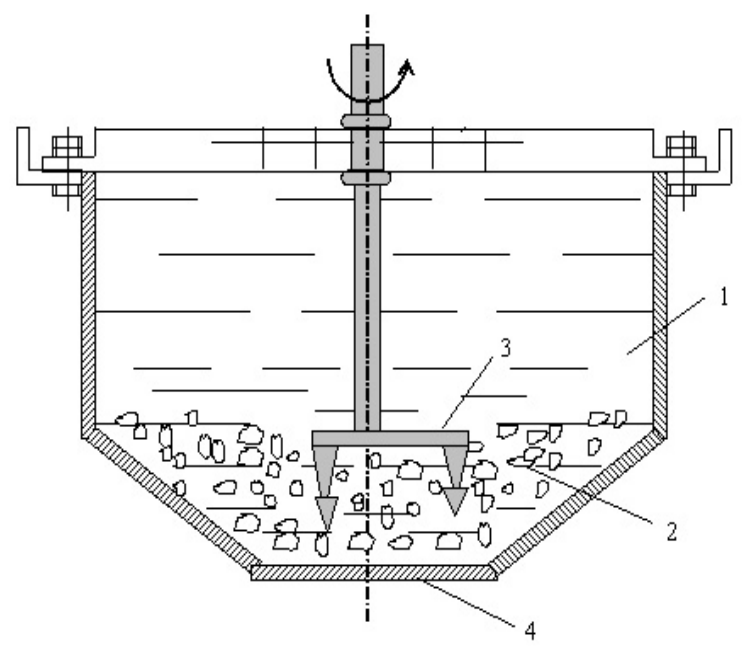

1 - working capacity; 2 - organic mass; 3 - high voltage double electrode; 4 - negative electrode

Figure. Diagram of the crushing unit of an electrohydroimpulse installation for extracting grease from bone mass

When exposed to a pulse repetition rate of $7 \div 15 \mathrm{~Hz}$, shock waves arise in the aquatic environment, and water penetrating into the bone contributes to the destruction of the structure of the grease source which contains grease displacing it. In this regard, the effect of destruction of the bone structure and the transition of fat mass in the solution. The frequency range is set on the basis of experimental studies.

The temperature in the range of $32-50^{\circ} \mathrm{C}$ allows to destroy the grease and remove from it a valuable component - fat. At temperatures below $32{ }^{\circ} \mathrm{C}$, part of the grease is retained by the destroyed tissue (pits) as a result of adsorption and capillarity. The viscosity and surface tension of the grease increase, and the extraction process slows down.

Studies of the electro-impulse method shows that impulses arising due to the electrohydraulic effect are sufficient to destroy the bonds that keep fat cells in the tissue.

The impact of the underwater spark discharge on the degree of degreasing was investigated at a voltage on the switching device of $10 \mathrm{kV}$; capacitor capacitance 0,$1 ; 0.2 ; 0.25 ; 0.4 ; 0.5 \mu \mathrm{F}$. The experiments were carried out with bones of cattle (Table 1) with the following parameters.

T a b l e 1

The main parameters of bone mass

\begin{tabular}{|l|c|c|c|c|c|}
\hline \multirow{2}{*}{ Bone name } & \multicolumn{5}{c|}{ Components, \% } \\
\cline { 2 - 6 } & grease & collagen & other proteins & ash & water \\
\hline Spine & 20 & 12 & 6 & 25 & 37 \\
\hline Chest bone & 14 & 9 & 10 & 16 & 51 \\
\hline Pelvic bone & 22 & 13 & 4 & 32 & 29 \\
\hline
\end{tabular}

Bone degreasing occurs under the influence of an underwater spark discharge and cavitation of a gas bubble, with a high-voltage discharge in water. The degree of extraction depends on the electrical parameters of the electrohydroimpulse installation and the temperature of the mixture in the crushing and grinding unit. Tables 2-6 present quantitative data on the effect of capacitor battery capacity on the degree of extracting grease from bone mass at various values of voltage $U$, discharge gap length $l_{P}$ at the switching device, and mixture temperature. 
Table 2

The effect of the capacitance battery of an electrohydroimpulse unit for the degreasing of crushed bone (at $U=10 \mathrm{kV}, l_{P}=7 \mathrm{~mm}, t_{\text {mix }}=32{ }^{\circ} \mathrm{C}$ )

\begin{tabular}{|l|c|c|c|c|c|}
\hline \multirow{2}{*}{ Bone name } & \multicolumn{5}{|c|}{ Initial data of bone mass $d_{\text {frac }}=10 \mathrm{~mm}$} \\
\cline { 2 - 6 } & $\begin{array}{c}\text { \% grease before } \\
\text { processing }\end{array}$ & $0.2 \mu \mathrm{F}$ & $0.25 \mu \mathrm{F}$ & $0.4 \mu \mathrm{F}$ & $0.5 \mu \mathrm{F}$ \\
\cline { 3 - 6 } & 20 & 12.7 & 13.3 & 14.1 & 14.5 \\
\hline Spine & 14 & 8.8 & 9.0 & 9.0 & 8.9 \\
\hline Chest bone & 22 & 14.5 & 15.7 & 16.1 & 16.2 \\
\hline Pelvic bone & &
\end{tabular}

Table 3

The effect of the capacitance battery of an electrohydroimpulse unit for the degreasing of crushed bone (at $U=15 \mathrm{kV}, l_{P}=7 \mathrm{~mm}, t_{\text {mix }}=32{ }^{\circ} \mathrm{C}$ )

\begin{tabular}{|c|c|c|c|c|c|}
\hline \multirow{3}{*}{ Bone name } & \multicolumn{5}{|c|}{ Initial data of bone mass $d_{f r a c}=10 \mathrm{~mm}$} \\
\hline & \multirow{2}{*}{$\begin{array}{c}\% \text { grease before } \\
\text { processing }\end{array}$} & \multicolumn{4}{|c|}{$\%$ release of grease after processing } \\
\hline & & $0.2 \mu \mathrm{F}$ & $0.25 \mu \mathrm{F}$ & $0.4 \mu \mathrm{F}$ & $0.5 \mu \mathrm{F}$ \\
\hline Spine & 20 & 14.6 & 14.6 & 16.3 & 16.5 \\
\hline Chest bone & 14 & 9.7 & 10.0 & 10.3 & 10.6 \\
\hline Pelvic bone & 22 & 16.6 & 17.5 & 18.2 & 18.2 \\
\hline
\end{tabular}

Ta b l e 4

The effect of the capacitance battery of an electrohydroimpulse unit for the degreasing of crushed bone (at $U=20 \mathrm{kV}, l_{P}=7 \mathrm{~mm}, t_{\text {mix }}=32^{\circ} \mathrm{C}$ )

\begin{tabular}{|l|c|c|c|c|c|}
\hline \multirow{2}{*}{ Bone name } & \multicolumn{5}{c|}{ Initial data of bone mass $d_{\text {frac }}=10 \mathrm{~mm}$} \\
\cline { 2 - 6 } & $\begin{array}{c}\text { \% grease before } \\
\text { processing }\end{array}$ & $0.2 \mu \mathrm{F}$ & $0.25 \mu \mathrm{F}$ & $0.4 \mu \mathrm{F}$ & $0.5 \mu \mathrm{F}$ \\
\cline { 3 - 6 } & 20 & 15.0 & 15.1 & 17.1 & 17.2 \\
\hline Spine & 14 & 10.2 & 10.4 & 11.0 & 11.3 \\
\hline Chest bone & 22 & 17.2 & 18.0 & 19.0 & 18.2 \\
\hline Pelvic bone & &
\end{tabular}

The effect of the capacitance battery of an electrohydroimpulse unit for the degreasing of crushed bone (at $U=10 \mathrm{kV}, l_{P}=7 \mathrm{~mm}, t_{\text {mix }}=32^{\circ} \mathrm{C}$ )

\begin{tabular}{|c|c|c|c|c|c|}
\hline \multirow{3}{*}{ Bone name } & \multicolumn{5}{|c|}{ Initial data of bone mass $d_{f r a c}=10 \mathrm{~mm}$} \\
\hline & \multirow{2}{*}{$\begin{array}{l}\% \text { grease before } \\
\text { processing }\end{array}$} & \multicolumn{4}{|c|}{$\%$ release of grease after processing } \\
\hline & & $0.2 \mu \mathrm{F}$ & $0.25 \mu \mathrm{F}$ & $0.4 \mu \mathrm{F}$ & $0.5 \mu \mathrm{F}$ \\
\hline Spine & 20 & 15.0 & 15.1 & 17.1 & 17.2 \\
\hline Chest bone & 14 & 10.1 & 10.6 & 11.2 & 11.2 \\
\hline Pelvic bone & 22 & 17.4 & 18.1 & 19.0 & 18.1 \\
\hline
\end{tabular}

Table 6

The effect of the capacitance battery of an electrohydroimpulse unit for the degreasing of crushed bone (at $U=25 \mathrm{kV}, l_{P}=9 \mathrm{~mm}, t_{\text {mix }}=38^{\circ} \mathrm{C}$ )

\begin{tabular}{|l|c|c|c|c|c|}
\hline \multirow{2}{*}{ Bone name } & \multicolumn{5}{c|}{ Initial data of bone mass $d_{\text {frac }}=10 \mathrm{~mm}$} \\
\cline { 2 - 6 } & $\begin{array}{c}\text { \% grease before } \\
\text { processing }\end{array}$ & $0.2 \mu \mathrm{F}$ & $0.25 \mu \mathrm{F}$ & $0.4 \mu \mathrm{F}$ & $0.5 \mu \mathrm{F}$ \\
\cline { 3 - 6 } & 20 & 15.3 & 15.5 & 17.4 & 17.2 \\
\hline Spine & 14 & 10.4 & 10.8 & 11.4 & 11.3 \\
\hline Chest bone & 22 & 17.8 & 18.4 & 19.0 & 18.7 \\
\hline Pelvic bone & &
\end{tabular}


T a b l e 7

The effect of the capacitance battery of an electrohydroimpulse unit for the degreasing of crushed bone (at $U=25 \mathrm{kV}, l_{P}=10 \mathrm{~mm}, t_{\text {mix }}=42{ }^{\circ} \mathrm{C}$ )

\begin{tabular}{|l|c|c|c|c|c|}
\hline \multirow{2}{*}{ Bone name } & \multicolumn{5}{|c|}{ Initial data of bone mass $d_{\text {frac }}=10 \mathrm{~mm}$} \\
\cline { 2 - 6 } & $\begin{array}{c}\text { \% grease before } \\
\text { processing }\end{array}$ & $0.2 \mu \mathrm{F}$ & $0.25 \mu \mathrm{F}$ & $0.4 \mu \mathrm{F}$ & $0.5 \mu \mathrm{F}$ \\
\cline { 3 - 6 } & 20 & 16.5 & 16.8 & 18.1 & 18.0 \\
\hline Spine & 14 & 11.1 & 11.4 & 12.0 & 11.9 \\
\hline Chest bone & 22 & 18.3 & 18.7 & 19.6 & 19.4 \\
\hline Pelvic bone & \multicolumn{4}{|c|}{ \% release of grease after processing } \\
\hline
\end{tabular}

Table 8

The effect of the capacitance battery of an electrohydroimpulse unit for the degreasing of crushed bone (at $U=25 \mathrm{kV}, l_{P}=12 \mathrm{~mm}, t_{\text {mix }}=44^{\circ} \mathrm{C}$ )

\begin{tabular}{|c|c|c|c|c|c|}
\hline \multirow{3}{*}{ Bone name } & \multicolumn{5}{|c|}{ Initial data of bone mass $d_{f r a c}=10 \mathrm{~mm}$} \\
\hline & \multirow{2}{*}{$\begin{array}{l}\% \text { grease before } \\
\text { processing }\end{array}$} & \multicolumn{4}{|c|}{$\%$ release of grease after processing } \\
\hline & & $0.2 \mu \mathrm{F}$ & $0.25 \mu \mathrm{F}$ & $0.4 \mu \mathrm{F}$ & $0.5 \mu \mathrm{F}$ \\
\hline Spine & 20 & 17.0 & 17.3 & 18.5 & 18.4 \\
\hline Chest bone & 14 & 11.7 & 11.9 & 12.4 & 12.3 \\
\hline Pelvic bone & 22 & 19.1 & 19.3 & 20.0 & 19.8 \\
\hline
\end{tabular}

Ta b l e 9

The effect of the capacitance battery of an electrohydroimpulse unit for the degreasing of crushed bone (at $U=30 \mathrm{kV}, l_{P}=12 \mathrm{~mm}, t_{\text {mix }}=44^{\circ} \mathrm{C}$ )

\begin{tabular}{|l|c|c|c|c|c|}
\hline \multirow{2}{*}{ Bone name } & \multicolumn{5}{|c|}{ Initial data of bone mass $d_{\text {frac }}=10 \mathrm{~mm}$} \\
\cline { 2 - 6 } & $\begin{array}{c}\text { \% grease before } \\
\text { processing }\end{array}$ & $0.2 \mu \mathrm{F}$ & $0.25 \mu \mathrm{F}$ & $0.4 \mu \mathrm{F}$ & $0.5 \mu \mathrm{F}$ \\
\cline { 3 - 6 } & 20 & 17.1 & 17.3 & 18.6 & 18.7 \\
\hline Spine & 14 & 11.8 & 12.0 & 12.4 & 12.4 \\
\hline Chest bone & 22 & 19.5 & 19.3 & 20.1 & 19.9 \\
\hline Pelvic bone & &
\end{tabular}

\section{Conclusion}

From the obtained laboratory data it can be seen that the voltage on the switching device should be $U=25 \mathrm{kV}$, the length of the discharge gap, $l_{P}=12 \mathrm{~mm}$, and the mixture temperature $t_{\text {mix }}=44^{\circ} \mathrm{C}$, the optimal value of the capaity of capacitor battery is about $C=0.4 \mu \mathrm{F}$ for maximum greave extraction from the bone mass. The repetition rate of the discharges was established from experimental data of $7 \mathrm{~Hz}$ for optimal defatting of the bone mass.

\section{References}

1 Соколов А.А. Технология мяса и мясопродуктов: учебник / А.А. Соколов. - М.: Пищ. пром-сть, 1970. - 740 с.

2 Стабников В.Н. Процессы и аппараты пищевых производств: учебник / В.Н. Стабников, В.И. Баранцев. — М.: Агропромиздат, 1985. - 509 с.

3 Лысянский В.М. Экстрагирование в пищевой промышленности: учебник / В.М. Лысянский, С.М. Гребенюк. - М.: Агропромиздат, 1987. - 187 с.

4 Либерман С.Г. Производство пищевых животных жиров на мясокомбинатах: учебник / С.Г. Либерман. - М.: Пищ. пром-сть, 1982. - $256 \mathrm{c}$.

5 Джафаров А.Ф. Производство желатина: учебник / А.Ф. Джафаров. - М.: Агропромиздат, 1990. - 287 с.

6 Нусупбеков Б.Р. Влияние температуры на электрогидравлический способ извлечения жира из костной массы / Б.Р. Нусупбеков, А.Ж. Сатыбалдин, Г.Е. Сейсенбек // Вестн. Караганд. ун-та. Сер. Физика. — 2001. — № 1(21). — С. 103106.

7 Kusainov K.K. An elektrohydraulic metod of removal of fat from bones / K.K. Kusainov, B.R. Nusupbekov, G.E. Seisenbek // Eurasian Physical Technical Journal. — 2007. — Vol.4, No. 2(8). — P. 57-61. 
8 Сейсенбек Г.Е. Энергетические характеристики электрогидроимпульсного способа извлечения жира и белка из костной массы / Г.Е. Сейсенбек, Б.Р. Нусупбеков, К. Кусаиынов // Вестн. Евразийск. нац. ун-та им. Л.Н. Гумилева. Сер. физическая. - 2008. - № 2(62). - С. 165-173.

9 Нусупбеков Б.Р. Способ обезжиривания костного сырья / Б.Р. Нусупбеков, Г.Е. Сейсенбек, Г.М. Шаймерденова, Р.С. Турлыбекова // Научная жизнь. - 2009. - № 2. - С. 30-33.

\title{
Б.Р. Нусупбеков, Г.Т. Картбаева, М. Стоев, А.К. Хасенов, Д.Ж. Карабекова, А.К. Муратова \\ Сүйек майын алудың электргидроимпульстік әдісі
}

\begin{abstract}
Майды бөліп алу тағамдық мал майларын өндірудің технологиялық процесінің маңызды сатысы болып табылады. Зерттеудің міндеті май тінінің жасушаларынан майды алуды қамтамасыз ету болып табылады. Сондықтан май жасушаларынан өнімді бөліп алу үшін май ткандарына әсер ететін әртүрлі технологиялық тәсілдер қолданылуы мүмкін. Желатин өндіру үшін сүйек майын алудың электргидроимпульстік әдісі әзірленді. Сүйек массасынан май алудың электргидроимпульстік әдісі сүйек массасының механикалық соққысына ұшырамауымен ерекшеленеді. Қоспада электргидроимпульсті қондырғымен қалыптасатын соққы толқыны пайда болады. Ірі қара малдың сүйек массасынан май алу бойынша тәжірибелік электргидроимпульстік қондырғыны сынау ірі қара малдың түрлі сүйектері үшін жүргізілді. Мақалада сүйек массасынан май алу үшін электргидроимпульсті қондырғының ұнтақтау торабының схемасы келтірілген. Зертханалық зерттеулер кезінде электргидроимпульсті қондырғының конденсатор батареясы сыйымдылығының, разряд кернеуі мәндерінің, коммутациялық құрылғыдағы разряд аралықтың ұзындығының, қоспа температурасының әртүрлі мәндерінде ұсақталған сүйекті майсыздандыру жұмыстары орындалып, сүйек массасын оңтайлы майсыздандыру үшін тиімді параметрлер тағайындалды.
\end{abstract}

Кілт сөздер: сүйек майын алу, ұсақтау торабы, электргидравликалық әдіс, коммутациялық құрылғы, разряд аралығының ұзындығы.

Б.Р. Нусупбеков, Г.Т. Картбаева, М. Стоев, А.К. Хасенов, Д.Ж. Карабекова, А.К. Муратова

\section{Электрогидроимпульсный метод извлечения костного жира}

\begin{abstract}
Извлечение жира является важнейшей стадией технологического процесса производства пищевых животных жиров. Задача исследования заключается в обеспечении извлечения жира из жировых клеток жировой ткани. Поэтому возможны различные технологические приемы, позволяющие воздействовать на жировую ткань таким образом, чтобы выделить из жировых клеток содержащийся в них жир. Разработан электрогидроимпульсный метод извлечения костного жира для производства желатина который отличается тем, что костные массы не подвергаются механическим ударам. В смеси образуется ударная волна, которая создается с помощью электрогидроимпульсной установки. Испытания экспериментальной электрогидроимпульсной установки по извлечению жира из костной массы крупного рогатого скота проводились для различных костей крупного рогатого скота. В статье приведена схема дробильного узла электрогидроимпульсной установки для извлечения жира из костной массы. При лабораторных исследованиях выполнены работы по обезжириванию измельченной кости при различных значениях емкости конденсаторной батареи электрогидроимпульсной установки, значений напряжения разряда, длины разрядного промежутка на коммутирующем устройстве, температуры смеси и установлены эффективные параметры для оптимального обезжиривания костной массы.
\end{abstract}

Ключевые слова: извлечения костного жира, дробильный узел, электрогидравлический метод, коммутирующее устройство, длина разрядного промежутка.

\section{References}

1 Sokolov, A.A. (1970). Tekhnolohiia miasa i miasoproduktov [Meat and meat products technology]. Moscow: Pishchevaia promyshlennost [in Russian].

2 Stabnikov, V.N., \& Barantsev, V.I. (1985). Protsessy i apparaty pishchevykh proizvodstv [Processes and apparatus of food production]. Moscow: Ahropromizdat [in Russian].

3 Lysyanskiy, V.M., \& Grebenyuk, S.M. (1987). Ekstrahirovanie v pishchevoi promyshlennosti [Extraction in the food industry]. Moscow: Ahropromizdat [in Russian]. 
4 Liberman, S.G. (1982). Proizvodstvo pishchevykh zhivotnykh zhirov na myasokombinatakh [Production of animal fats in meat processing plants]. Moscow: Pishchevaia promyshlennost [in Russian].

5 Dzhafarov, A.F. (1990). Proizvodstvo zhelatina [Gelatin production]. Moscow: Agropromizdat [in Russian].

6 Nusupbekov, B.R., Satybaldin, A.Zh., \& Seysenbek, G.E. (2001). Vliianie temperatury na elektrohidravlicheskii sposob izvlecheniia zhira iz kostnoi massy [The effect of temperature on the electrohydraulic method of extracting fat from bone mass]. Vestnik Karahandinskoho universiteta. Seriia Fizika - Bulletin of the Karaganda University. Physics series, 1(21), 103-106 [in Russian].

7 Kusainov, K.K., Nusupbekov, B.R., \& Seisenbek, G.E. (2007). An elektrohydraulic metod of removal of fat from bones. Eurasian Physical Technical Journal, 4, 2(8), 57-61.

8 Seysenbek, G.E., Nusupbekov, B.R., \& Kusaiynov, K. (2008). Enerheticheskie kharakteristiki elektrohidroimpulsnoho sposoba izvlecheniia zhira i belka iz kostnoi massy [Energy characteristics of the electrohydroimpulse method for extracting fat and protein from bone mass]. Vestnik Evraziiskoho natsionalnoho universiteta imeni L.N. Gumilyova. Seriia fizika - Bulletin of L.N. Gumilyov Eurasian national University, Physics series, 2(62), 165-173 [in Russian].

9 Nusupbekov, B.R., Seysenbek, G.E., Shaymerdenova, G.M., \& Turlybekova, R.S. (2009). Sposob obezzhirivaniia kostnoho syria [Method of degreasing bone raw materials]. Nauchnaia zhizn - Scientific life, 2, 30-33 [in Russian]. 